\title{
Case Report: A Truck Driver with Pelvic Pain
}

\author{
Olgu Sunumu: Pelvik Ağrısı Olan Bir Kamyon Şoförü
}

\author{
(1) Nathan J. Rademaker1, (1) William C. Dooley², (1) Christian El Amm³ , (1) Jeremy White ${ }^{4}$, (1) Brian W. Cross ${ }^{1}$ \\ IUniversity of Oklahoma Health Sciences Center, Department of Urologic Surgery, Oklahoma City, USA \\ 2University of Oklahoma Health Sciences Center, Department of Surgery, Oklahoma City, USA \\ ${ }^{3}$ University of Oklahoma Health Sciences Center, Department of Plastic and Reconstructive Surgery, Oklahoma City, USA \\ ${ }^{4}$ University of Oklahoma Health Sciences Center, Department of Orthopedic Surgery, Oklahoma City, USA
}

\section{Abstract}

Extraskeletal myxoid chondrosarcoma (EMC) is a relatively rare soft tissue malignancy, originally described in the 1950s and characterized as a distinct entity from chondrosarcoma of the bone in the 1970s. These tumors most commonly originate in the proximal extremities, and their occurrence in the genitourinary tract is exceedingly rare, with few case reports citing origination in its component organs. We present a clinical case report of an EMC originating from the base of the penis with significant local involvement of the bony pelvis.

Keywords: Extraskeletal, Myxoid, Chondrosarcoma, Genitourinary

\section{Öz}

Ekstraskeletal miksoid kondrosarkom (EMK), başlangıçta 1950'li yıllarda tarif edilen ve 1970'li yıllarda kemik kondrosarkomundan ayrı bir varlık olarak karakterize edilen, nispeten nadir yumuşak doku malignitesidir. Bu tümörler en sık proksimal ekstremitelerden köken alırlar, genitoüriner sistemde görülme sıklığı son derece nadirdir ve komponent organlardan köken alan az sayıda olgu sunumu mevcuttur. Kemik pelvisinin anlamlı lokal tutulumu ile birlikte penis tabanından kaynaklanan EMK'li klinik bir olgu sunuyoruz.

Anahtar Kelimeler: Ekstraskeletal, Miksoid, Kondrosarkom, Genitoüriner

\section{Introduction}

Extraskeletal myxoid chondrosarcoma (EMC) is a rare type of sarcoma of the soft tissues that usually presents as a slowgrowing mass in men in their 50-60s $(1,2)$. They are distinct from chondrosarcoma, and are characterized by a multinodular growth of primitive chondroblast-like cells in an abundant myxoid matrix. Most patients present with tumor development in the proximal extremities and show slow progression of disease; however, late local recurrence and metastases do occur (2). The presence of this type of tumor in the soft tissues of the genitourinary tract was first described in 1973 with its presence noted in the scrotum (3). Subsequent case reports have re-demonstrated its presence in the scrotum as well as its occurrence in the spermatic cord, perineum and vulva; however these cases appear to be extremely rare. We present a case report of an EMC originating at the base of the penis, as well as a review of the literature on this rare entity.

\section{Case Presentation}

A 63-year-old male presented to our institution for evaluation due to a painful mass overlying his suprapubic area that had begun to interfere with his occupation. He noted the mass was first noticed around one year prior to his presentation, but that it seemed to grow rapidly over the few months prior to him seeking medical attention. Other than discomfort, he had relatively few symptoms with no constitutional or voiding symptoms. On physical examination, he had a large, non-mobile, firm mass that encompassed the suprapubic area and tracked into both inguinal creases. This area was overlying the regional lymph nodes, so adenopathy was not able to be assessed. A computed tomography scan showed a large suprapubic mass surrounding the base of the penis. He underwent an open, excisional biopsy in the operating room with pathology showing EMC. Following pathologic diagnosis, a contrast-enhanced magnetic resonance

Correspondence: Nathan J. Rademaker MD, University of Oklahoma Health Sciences Center, Department of Urologic Surgery, Oklahoma City, USA E-mail: nathan-rademaker@ouhsc.edu ORCID-ID: orcid.org/0000-0002-3430-0517 Received: 26.05.2017 Accepted: 14.09.2017

Cite this article as: Rademaker NJ, Dooley WC, El Amm C, White J, Cross BW. Case Report: A Truck Driver with Pelvic Pain. J Urol Surg 2018;5(3):194-196. oCopyright 2018 by the Association of Urological Surgery / Journal of Urological Surgery published by Galenos Publishing House. 
imaging of the abdomen and pelvis was obtained that showed a heterogeneous lobulated mass infiltrating the soft tissues around the base of the penis, extending into the perineum with left-sided extension above the urogenital diaphragm and extending out the left sciatic notch (Figure 1). His metastatic survey was negative.

A multidisciplinary case was undertaken with the urology, orthopedic surgery, surgical oncology, and plastic and reconstructive surgery services. Radical excision of a $28.5 \mathrm{~cm}$ tumor was performed that included total penectomy with perineal urethrostomy, right orchiectomy due to tumor invasion of the right spermatic cord, left orchiopexy, complex scrotoplasty, radical resection of the bilateral pubis, superior rami and inferior rami and complicated recreation and closure of the pelvic floor musculature (Figure 2). A double layer of biological graft material was folded and sutured for a $2 \mathrm{~cm}$ four-layer central band to become the replacement neopubis. This was bone anchored in place and anterior and posterior flaps were utilized to rebuild missing anterior abdominal wall musculature by suturing the back layer inside and anterior to external muscle fascia. Pelvic floor reconstruction was then performed by attaching both layers to ischium via bone anchors and the bladder neck was re-suspended from the neopubis, opening in layers for urethral passage. Lastly, soft tissue external coverage was created by rotational regional flaps. He was admitted to the intensive care unit postoperatively for flap checks. On postoperative day two, his flap began to appear ischemic and he was taken back to the operating room for debridement of the anterolateral thigh flap with subsequent replacement with a vertical rectus abdominis myocutaneous flap. Following this, he had an uneventful remaining postoperative course and he was discharged home on oral antibiotics with a Foley catheter, multiple Jackson-Pratt (JP) drains and home health for dressing changes. He has been seen in follow-up with subsequent removal of his Foley catheter and JP drains. His surgical sites and flap remain healthy and viable. The pathological margins were negative and microscopic histology demonstrated rearrangement of the NR4A3 (9q31.1) and EWSR1 (22q12) genes in 90\% of cells, consistent with the pathological diagnosis of EMC. He will be followed with serial imaging at three months intervals.

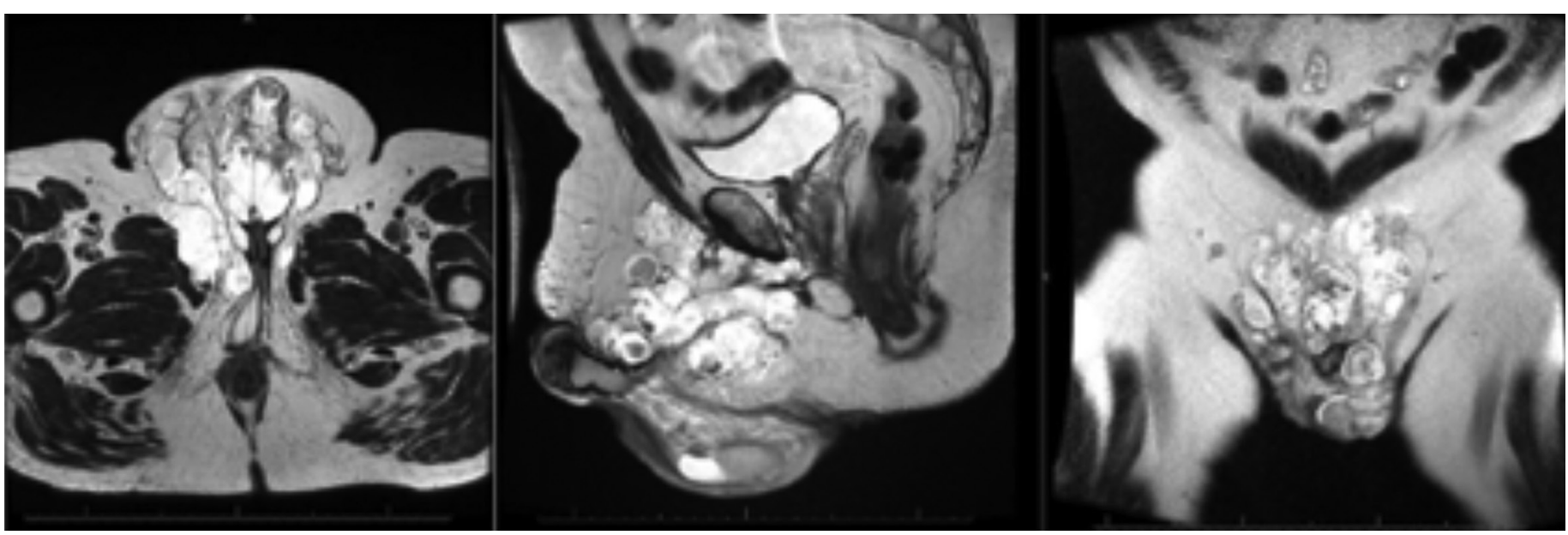

Figure 1. 3 Tesla magnetic resonance imaging of the pelvis showing diffuse tumor involvement of the bony pelvis and its component organs

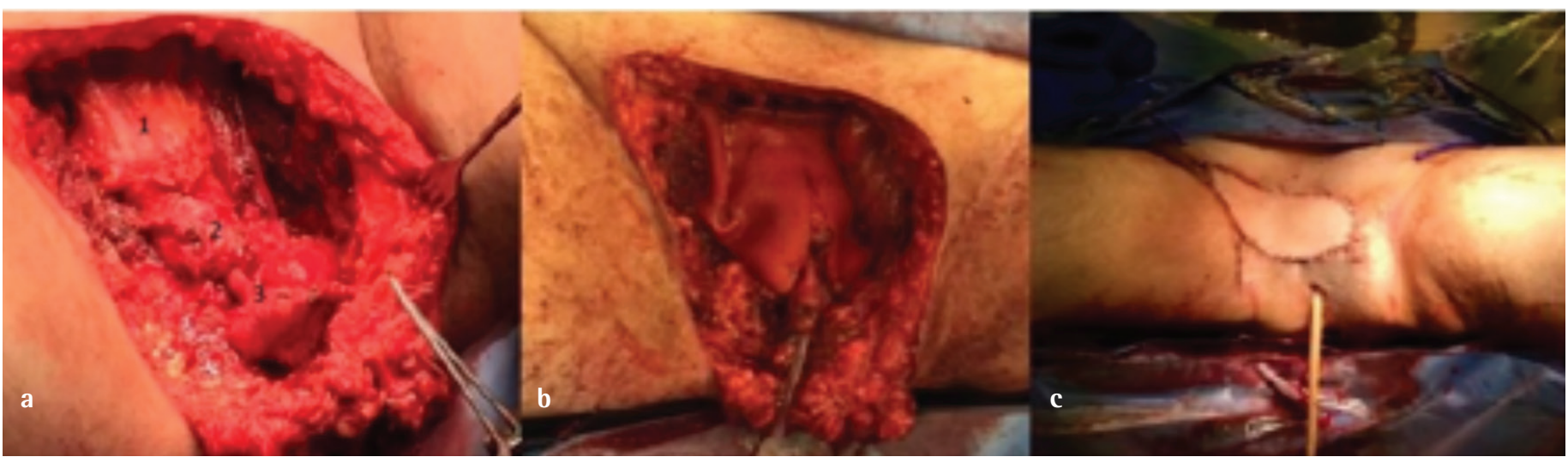

Figure 2. a) Radical pelvic mass excision undertaken by multidisciplinary team with dissection showing the following: 1- bladder, 2- prostate, 3- bulbar urethra, b) Pelvic floor reconstruction showing biological mesh and neo-pubis, c) Soft tissue coverage with regional rotational flaps 


\section{Discussion}

EMC is a rare soft tissue tumor that comprises $<3 \%$ of all sarcomas (4). They commonly develop in the deep compartments of the proximal extremities in the $5^{\text {th }}$ to $6^{\text {th }}$ decade with a 2:1 predilection for male patients (2).

EMC is a unique tumor with fusion (or chimeric) genes $(4,5,6)$. There have been four specific translocations identified, but the most common translocation is $t(9 ; 22)(q 22 ; q 12)$, found in approximately $75-80 \%$ of cases, which results in a fusion of EWSR1 gene at 22q12 to the nuclear receptor subfamily 4 , group $\mathrm{A}$, member 3 gene (NR4A3) at $9 \mathrm{q} 22$. Given their sensitivity and specificity, a combination of real-time polymerase chain reaction and fluorescent in situ hybridization is felt to be a sensitive and specific method for diagnosis (4).

As noted above, EMC is usually discovered as a localized process with only $10-15 \%$ of patients having metastasis at presentation. They do; however, have a propensity for local recurrence and metastasis despite an indolent course. Large tumors $(>10 \mathrm{~cm})$ and metastatic disease at diagnosis are indicative of a poor prognosis. Patients presenting without metastatic disease have been shown to have a $35-40 \%$ chance of developing local recurrence by 3.5 years. The risk of subsequent development of distant recurrence or metastasis is thought to be around $25-30 \%$ by 3.5 years. Recent retrospective reviews show 5 , 10 , and 15 -year overall survival rates of $82 \%, 65 \%$, and $58 \%$, respectively (7).

Surgical resection is the mainstay of treatment, but there are limited data regarding options for the treatment of unresectable or metastatic disease $(2,7,8)$. Chemotherapy appears to have minimal benefit in the treatment of this disease process, with poor response rates noted across several studies $(7,8)$. More recently, sunitinib has shown some promise in small studies with genotypic/phenotypic analyses that support a correlation between chemotherapeutic response and the presence of the EWSR1-NR4A3 fusion gene (9).

\section{Ethics}

Informed Consent: It was taken.

Peer-review: Externally peer-reviewed.

\section{Authorship Contributions}

Surgical and Medical Practices: B.W.C., W.C.D., C.E.A., J.W., Concept: N.J.R., B.W.C., Design: N.J.R., B.W.C., Data Collection or Processing: N.J.R., Analysis or Interpretation: N.J.R., Literature Search: N.J.R., Writing: N.J.R., B.W.C., W.C.D., C.E.A., J.W.

Conflict of Interest: No conflict of interest was declared by the authors.

Financial Disclosure: The authors declared that this study received no financial support.

\section{References}

1. Enzinger F, Shiraki M. Extraskeletal myxoid chondrosarcoma. An analysis of 34 cases. Hum Pathol 1972;3:421-435.

2. Kawaguchi S, Wada T, Nagoya S, Ikeda T, Isu K, Yamashiro K, Kawai A, Ishii T, Araki N, Myoui A, Matsumoto S, Umeda T, Yoshikawa $H$, Hasegawa $T$; Multi-Institutional Study of 42 Cases in Japan. Extraskeletal myxoid chondrosarcoma: a multi-institutional study of 42 cases in Japan. Cancer 2003;97:1285-1292.

3. Angervall L, Enerbäck L, Knutson H. Chondrosarcoma of soft tissue origin. Cancer 1973;32:507-513.

4. Benini S, Cocchi S, Gamberi G, Magagnoli G, Vogel D, Ghinelli C, Righi A, Picci $P$, Alberghini M, Gambarotti M. Diagnostic utility of molecular investigation in extraskeletal myxoid chondrosarcoma. J Mol Diagn 2014;16:314-323.

5. Hisaoka $\mathrm{M}$, Hasimoto $\mathrm{H}$. Extraskeletal myxoid chondrosarcoma: Updated clinicopathological and molecular genetic characteristics. Pathol Int 2005;55:453-463.

6. Letson $\mathrm{G}$, Muro-Cacho CA. Genetic and molecular abnormalities in tumors of the bone and soft tissues. Cancer Control 2001;8:239-251.

7. Drilon AD, Popat S, Bhuchar G, D'Adamo DR, Keohan ML, Fisher C, Antonescu CR, Singer S, Brennan MF, Judson I, Maki RG. Extraskeletal Myxoid Chondrosarcoma: A Retrospective Review From 2 Referral Centers Emphasizing Long-term Outcomes With Surgery and Chemotherapy. Cancer 2008;113:3364-3371.

8. Patel S, Burgess M, Papadopoulos N, Linke KA, Benjamin RS. Extraskeletal myxoid chondrosarcoma. Long-term experience with chemotherapy. Am J Clin Oncol 1995;18:161-163.

9. Stacchiotti $S$, Pantaleo MA, Astolfi A, Dagrada GP, Negri T, Dei Tos AP, Indio V, Morosi C, Gronchi A, Colombo C, Conca E, Toffolatti L, Tazzari M, Crippa F, Maestro R, Pilotti S, Casali PG. Activity of sunitinib in extraskeletal myxoid chondrosarcoma. Eur J Cancer 2014;50:1657-1664. 